\title{
Differential permeability to horseradish peroxidase in affected and non-affected ventricular walls during postnatal development of normal and hydrocephalic hyh mice
}

\author{
Patricia Páez ${ }^{1}$, Ruth Roales-Buján ${ }^{1}$, Sara Rodríguez², Federico Bátiz², \\ Antonio J Jiménez ${ }^{1}$, Esteban M Rodríguez ${ }^{2}$ and José-Manuel Pérez-Fígares*1
}

\author{
Address: ${ }^{1}$ Departamento de Biología Celular, Genética y Fisiología, Universidad de Málaga, E-29071 Málaga, España and ²Instituto de Histología \\ y Patología, Universidad Austral de Chile, Valdivia, Chile \\ Email: José-Manuel Pérez-Fígares* - figares@uma.es \\ * Corresponding author
}

from 49th Annual Meeting of the Society for Research into Hydrocephalus and Spina Bifida

Barcelona, Spain, 29 June -2 July 2005

Published: 30 December 2005

Cerebrospinal Fluid Research 2005, 2(SuppI I):S3 I doi:I0.II86/I743-8454-2-SI-S3 I

\section{Background}

Hyh mutant mice suffer a congenital hydrocephalus triggered by ependyma denudation [1]. The ventricular surface in non hydrocephalic newborn mice is lined by the immature ependyma, which is characterized for being vimentin (-) and $S 100 \beta(-)$, at variance in the adult animals the mature ependyma expresses vimentin and $S 100 \beta$ [2]. On the other hand, in the hydrocephalic mice the ependyma begins to denudate on the 12th day of gestation, and at PN8 only some areas of lateral ventricle are still endowed with ependyma. In parallel, astroglia starts to cover the denuded surface forming a new cell layer, the glial scar, which lines the damaged ventricular surface. We have studied the permeability to horseradish peroxidase (HRP) of these four regions at the ventricular wills: mature ependyma, and denuded areas with or without glial scar.

\section{Materials and methods}

Control and hydrocephalic $h y h$ mice (Jackson Lab., USA) at 3rd and 30th day of post-natal life were injected into a lateral ventricle with 3\% HRP. 15 min after the injection the animals were sacrificed under anesthesia. HRP was detected by immunocitochemistry with specific antibodies. Inmunocitochemistry for PCNA (to label proliferating cells) and GFAP, S100 $\beta$ and vimentin was used

\section{Results}

In non-hydrocephalic mice the immature ependymal layer was impermeable to HRP, whereas the mature ependyma was permeable. In hydrocephalic animal the areas where the ependyma had detached and the glial scar had not yet form were permeable to HRP, diffusing through the parenchyma. The glial scar was recognized for being GFAP positive and surprisingly, vimentin positive. When this barrier was fully developed at PN-30, it was apparently impermeable. However, the presence in the neuropile of cells labelled with HRP might indicates that some HRP has passaged through the glial scar. In adult hydrocephalic animals, there are zones where the ependyma is not denuded. This ependyma and the neighbouring glial scar appear impermeable to HRP. However, the HRP labelling of subventricular structures in these levels suggest that some tracer has passed through.

\section{Conclusion}

The different permeability properties between mature and immature ependymal layers suggest that differences exist in cell adhesion features and permeability. In hydrocephalic mice, denudated areas devoid of glial scar are very permeable to HRP. Thus, ependymal denudation implies the loss of CSF-parenchyma barrier, which could influence the CNS development. In adult hidrocephalic mice there are ependimal patches that do not detach. This particular ependyma, as the glial layer lining the denuded area, prevents partially or completely the passage of HRP. The HRP labelling of subventricular structures in this two regions could be an indication that some HRP has passed through the non-detached ependyma and through the glial sheath by an as yet unknown mechanism. This suggests that these ependymal areas could correspond to an specific ependyma population that in the normal animal 
would be a tight ependyma, and that such an ependyma would have the same barrier properties as those of the glial scar. What actually are these barrier properties are being further investigated in our laboratory.

\section{Acknowledgements}

Suported by Grants from FIS, PI 0307556 and Red CIEN (C/0306), Instituto de Salud Carlos III, Consejeria de Salud, Junta de Andalucia, Spain to JMP-F; and Fondecyt 1030265, Chile to EMR

\section{References}

I. Jimenez AJ, Tome M, Paez P, Wagner C, Rodriguez S, Fernandez-Llebrez P, Rodriguez EM, Perez-Figares JM: A programmed ependymal denudation precedes congenital hydrocephalus in the hyh mutant mouse. I Neuropathol Exp Neurol 200I, 60(II):1105-19.

2. Bruni JE: Ependymal development, proliferation, and functions : a review. Microscopy research and technique 1998, 4I:2-13.

Publish with Biomed Central and every scientist can read your work free of charge

"BioMed Central will be the most significant development for disseminating the results of biomedical research in our lifetime. "

Sir Paul Nurse, Cancer Research UK

Your research papers will be:

- available free of charge to the entire biomedical community

- peer reviewed and published immediately upon acceptance

- cited in PubMed and archived on PubMed Central

- yours - you keep the copyright

Submit your manuscript here:

http://www.biomedcentral.com/info/publishing_adv.asp 